\title{
Application of Mass Spectrum Method in Determining Bioactive Compounds of the Essential Oil from Leaves and Stems of Clove (Syzigium aromaticum)
}

\author{
Akhmad Rifai ${ }^{1, *, a}$ and Nur Amin Riyadi ${ }^{1}$ \\ ${ }^{1}$ Department of Chemical Engineering, Politeknik Negeri Ujung Pandang, \\ Jl. Perintis Kemerdekaan KM 10, Makassar, 90245, Indonesia \\ *,a Email: arrifai82@poliupg.ac.id (Corresponding Author)
}

\begin{abstract}
The essential oil from leaves and stems of clove (Syzigium Aromaticum) growing in Siwa (South Sulawesi, Indonesia), was obtained by hydrodistillation and gas chromatography-mass spectrometry (GC-MS) was used to identify the constituent of the sample. There were five most bioactive compounds contained in the clove oil of the leaves and stems, namely eugenol, $\quad \beta$-caryophyllene, 1,4,7cycloundecatriene-1,5,9,9 tetramethyl, caryophyllene oxide, and cadinene. The eugenol compound, which is contained in the stems is $55.83 \%$ bigger than the leaves, which is $45.3 \%$. But on the contrary, other compounds in the leaves are $\beta$-caryophyllene $(25.57 \%), 1,4,7-$ cycloundecatriene-1,5,9,9 tetramethyl $(8.65 \%)$, caryophyllene oxide $(4.64 \%)$ and cadinene $(2.31 \%)$ greater than the other compounds in the stems, namely $\beta$-caryophyllene $(19.72 \%), 1,4,7-$ cycloundecatriene-1,5,9,9 tetramethyl $(4.38 \%)$, caryophyllene oxide $(3.48 \%)$ and cadinene $(0.5 \%)$. Eugenol is the major constituent of the clove oil that can be used in pharmacology as antivirus, antimicrobial, antiseptic, and industry of perfume.
\end{abstract}

Keywords—clove oil; eugenol; GC-MS

\section{Introduction}

Clove plant is one of the plant's species of vegetation that produces essential oils known as clove oil. Clove oil is one of the most abundant essential oils in Indonesia compared to other essential oils. Clove oil production in Indonesia is 3500 - 4000 tons per year [1], and Indonesia's clove oil supply to the world market is more than $60 \%$ of the world's needs [2].

Clove oil, in general, can be obtained through traditional methods [3], namely steam distillation. However, several methods have been carried out, including through the hydrodistillation method [4], supercritical carbon dioxide [5], and extraction ultrasound [6].
Essential extracts obtained were widely applied in the field of pharmacology. Clove oil can function as an anti-oxidant [7], antibacterial [8], antifungal [9], anesthetic [10], and analgesic [11].

Clove oil gives a distinctive aroma of essential originating from flowers (10-20\%), stems $(5-10 \%)$, and a small portion of the leaves [12]. Clove oil contains three large compositions, namely eugenol (70-85\%), eugenyl acetate (15\%), $\beta$-caryophyllene $(5-12 \%)$, and a small number of other bioactive compounds [12].

Gas chromatography-mass spectrometer (GC-MS) is the most popular method for the determination of essential oil composition. GC-MS enables compound identification by comparing the obtained mass spectra of the analytes with the library from the National Institute of Standards and Technology (NIST) and comparing their similarity index (SI) [13]. The work started here, aiming to fill the blank field through the analysis constituent of essential oil from extracted oil from leaves and stems of clove. GC-MS was employed to identify compounds in the extracted oil of sample, and It would reveal how many concentrations contained in the sample.

\section{Research Methodology}

\section{A. Material}

Dry leaves and stems of clove plants was collected directly from Siwa District, South Sulawesi of Indonesia and transport to chemistry laboratory of Politeknik Negeri Ujung Pandang. 


\section{B. Equipment}

Gas chromatography mass spectrometer QP-2010 ultra shimadzu coupled with AOC-20i autosampler using RTx-5 capilarry column (length $30 \quad \mathrm{~m}$ ) and hydrodistillation apparatus.

\section{Methods}

\section{Extraction of essential oil}

Extraction of clove oil by hydrodistillation method $500 \mathrm{~g}$ of sample was powdered using porcelain mortar and placed in a round bottom flask fitted with condenser hydro distillation. The distillation process for $3 \mathrm{~h}$ at atmospheric pressure and constant temperature $(70-80$ $\left.{ }^{\circ} \mathrm{C}\right)$. The strongly aromatic oil was separated from the water layer using diethyl eter, and removed the solvent by evaporation.

\section{GC-MS Analysis}

The GC-MS analysis achieved component identification. $1 \mathrm{~mL}$ of extract clove oil was dissolved in acetone and placed in a vial. The oven temperature of GC-MS was programmed commencing from $70{ }^{\circ} \mathrm{C}$ with a hold time of $2 \mathrm{~min}$, and the temperature was increased to $200{ }^{\circ} \mathrm{C}$ at a rate of $10{ }^{\circ} \mathrm{C} / \mathrm{min}$ and the final temperature was $280^{\circ} \mathrm{C}$ with a holding time of $9 \mathrm{~min}$ at a rate of $10{ }^{\circ} \mathrm{C} / \mathrm{min}$ so that the total time of analysis was 36 min. The mobile phase using helium carrier gas with a flow rate of $14 \mathrm{~mL} / \mathrm{min}$ and injector temperature 250 ${ }^{\circ} \mathrm{C}$ (splitless mode) with pressure $76.9 \mathrm{kPa}$. Ion source and interfaces of the mass spectrum were $200{ }^{\circ} \mathrm{C}$ and $280{ }^{\circ} \mathrm{C}$, respectively, which is solvent cut time $3 \mathrm{~min}$ and range of mass spectrum $400-700 \mathrm{~m} / \mathrm{z}$.

\section{Identification of components}

The components of essential oil were identified based on a comparison of their retention time and mass spectra with published data and computer matching with Wiley 8 and National Institute of Standards and Technology (NIST 2014) libraries provided with the computer controlling the GC-MS system, in Politeknik Negeri Ujung Pandang, Indonesia. The spectrum of the unknown components was compared with the spectrum of the known component stored in the library, the name, molecular weight and structure of the components of the test materials were ascertained.

\section{Results and Discussion}

\section{A. Chromatogram GC-MS}

The total number of components making up the clove oil sample in the leaves is 20 components, while in the stems, it is 30 components with different retention times, as shown in Figure 1 and Figure 2.

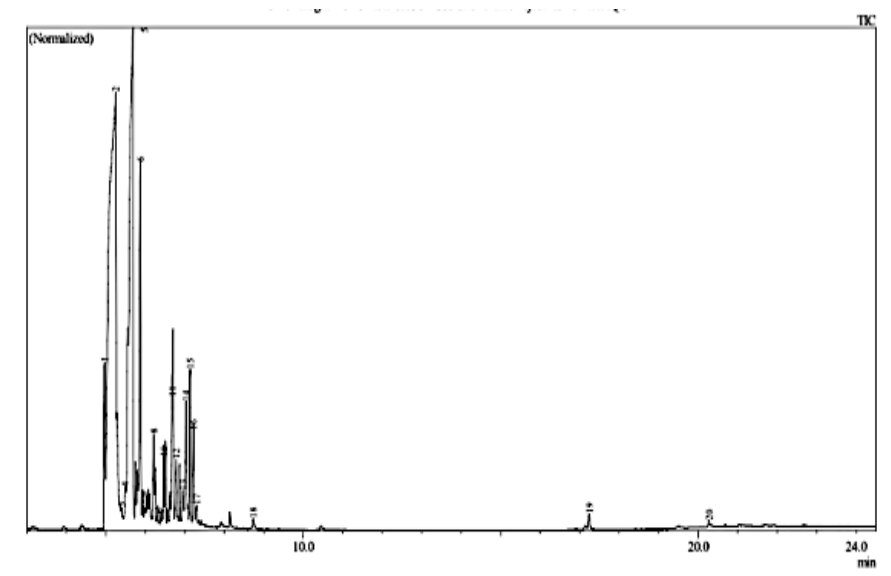

Figure 1. Chromatogram of clove leaf oil

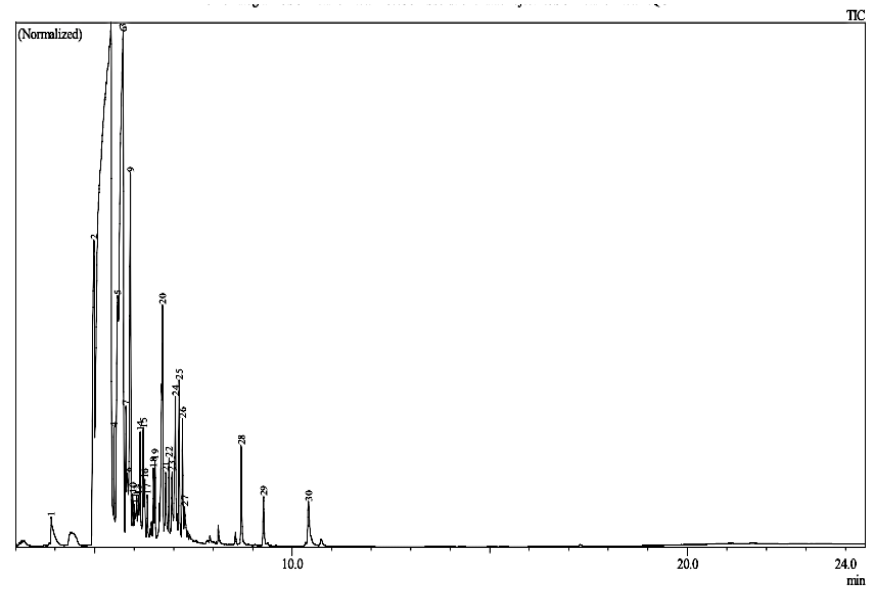

Figure 2. Chromatogram of clove stem oil

Based on the results of GC-MS analysis, there are five components of the most abundant constituent compounds in the two samples belonging to terpenoid class compounds, as shown in Table 1. Determination of the type of compound contained by the sample is determined based on the fragmentation of the mass spectrum $(\mathrm{m} / \mathrm{z})$ compared with similarity data mass spectrum $(\mathrm{m} / \mathrm{z})$ from library of instrument shown in Figures 3, 4, 5, 6, and 7 . 
Table 1. The major component of clove leaf oil and stem oil

\begin{tabular}{|c|c|c|c|c|c|}
\hline \multirow{2}{*}{$\begin{array}{c}\text { Active } \\
\text { Compounds }\end{array}$} & $\begin{array}{c}\text { Retention } \\
\text { Time } \\
(\mathrm{min})\end{array}$ & Leaf & Stem & Formula & $\begin{array}{c}\text { Molecul } \\
\text { ar } \\
\text { Weight } \\
(\mathrm{g} / \mathrm{mol})\end{array}$ \\
\hline Eugenol & 5.252 & 45.3 & 55.83 & $\begin{array}{c}\mathrm{C}_{10} \mathrm{H}_{12} \mathrm{O} \\
2\end{array}$ & 164 \\
\hline $\begin{array}{c}\beta- \\
\text { caryophyllene }\end{array}$ & 5.683 & $\begin{array}{c}25.5 \\
7\end{array}$ & 19.72 & $\mathrm{C}_{15} \mathrm{H}_{24}$ & 204 \\
\hline $\begin{array}{c}1,4,7- \\
\text { cycloundecatr } \\
\text { iene-1,5,9,9 } \\
\text { tetramethyl }\end{array}$ & 5.874 & 8.65 & 4.38 & $\mathrm{C}_{15} \mathrm{H}_{24}$ & 204 \\
\hline $\begin{array}{c}\text { Caryophyllen } \\
\text { e Oxide }\end{array}$ & 6.683 & 4.64 & 3.48 & $\mathrm{C}_{15} \mathrm{H}_{24} \mathrm{O}$ & 220 \\
\hline Cadinene & 6.215 & 2.31 & 0.5 & $\mathrm{C}_{15} \mathrm{H}_{24}$ & 204 \\
\hline
\end{tabular}

Eugenol has a molecular weight of $164 \mathrm{~g} / \mathrm{mol}$, and in the mass spectrum (figure 3 ), the compound gives a molecular ion (M+) at an $\mathrm{m} / \mathrm{z}$ value of 164 . The parent molecular ion produces a mass spectrum fragment (m/z): 164, 149, $131,121,103$ with a base peak of $\mathrm{m} / \mathrm{z} 164$.
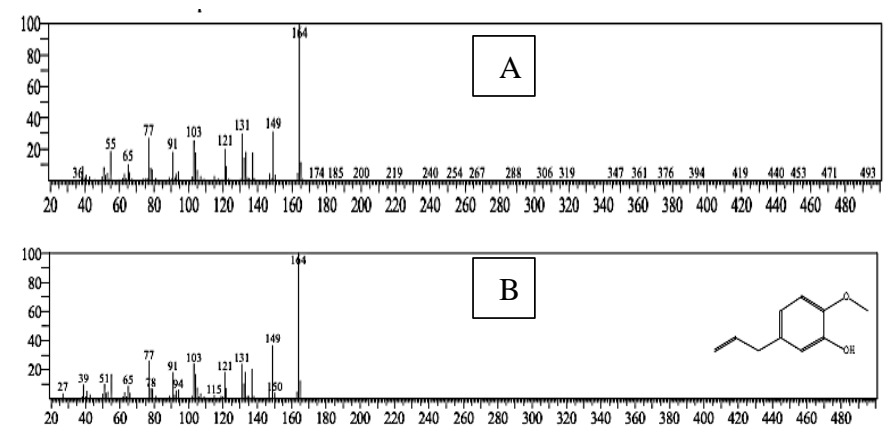

Figure 3. (A) Mass spectrum of sample compared with (B) mass spectrum library of eugenol with SI: 96

Caryophyllene has a molecular weight of $204 \mathrm{~g} / \mathrm{mol}$, and in the mass spectrum (figure 4), the compound gives a molecular ion $(\mathrm{M}+)$ at an $\mathrm{m} / \mathrm{z}$ value of 204 . The parent molecular ion produces a mass spectrum fragment (m/z): 204, 161, 133, 93, 79,69 with a base peak of $\mathrm{m} / \mathrm{z} 93$.

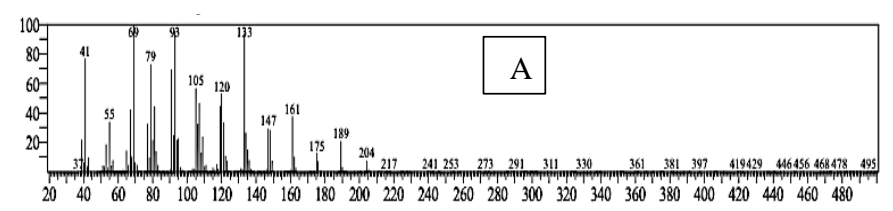

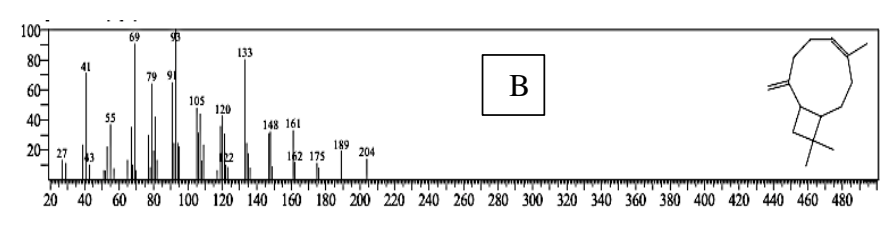

Figure 4. (A) Mass spectrum of sample compared with (B) mass spectrum library of caryophylle with SI: 96

1,4,7- cycloundecatriene-1,5,9,9 tetramethyl has a molecular weight of $204 \mathrm{~g} / \mathrm{mol}$, and in the mass spectrum (figure 5), the compound gives a molecular ion (M+) at an $\mathrm{m} / \mathrm{z}$ value of 204. The parent molecular ion produces a mass spectrum fragment $(\mathrm{m} / \mathrm{z}): 204,147,121,93,80$ with a base peak of $\mathrm{m} / \mathrm{z} 93$.
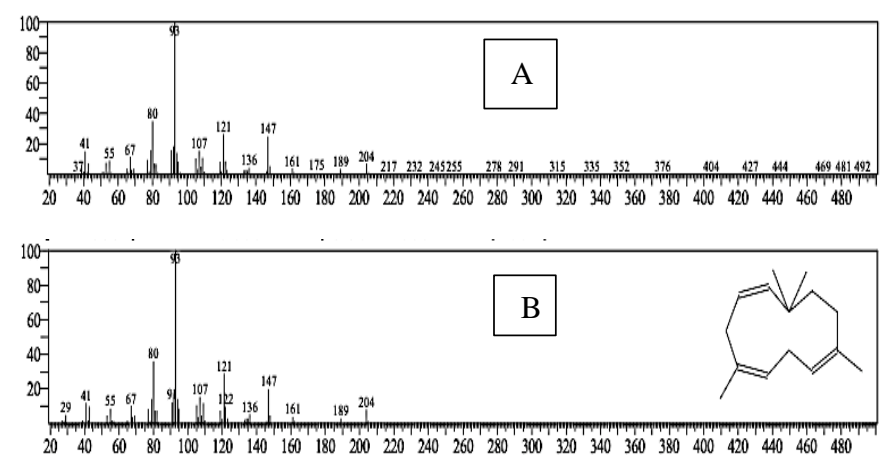

Figure 5. (A) Mass spectrum of sample compared with (B) mass spectrum library of 1,4,7- cycloundecatriene-1,5,9,9 tetramethyl with SI: 97

Caryophyllene oxide has a molecular weight of $171 \mathrm{~g} / \mathrm{mol}$, and in the mass spectrum (figure 6), the compound gives a molecular ion $(\mathrm{M}+)$ at an $\mathrm{m} / \mathrm{z}$ value of 171 . The parent molecular ion produces a mass spectrum fragment $(\mathrm{m} / \mathrm{z}): 177$, $121,109,93,79,69,55,43$ with a base peak of $\mathrm{m} / \mathrm{z} 43$.
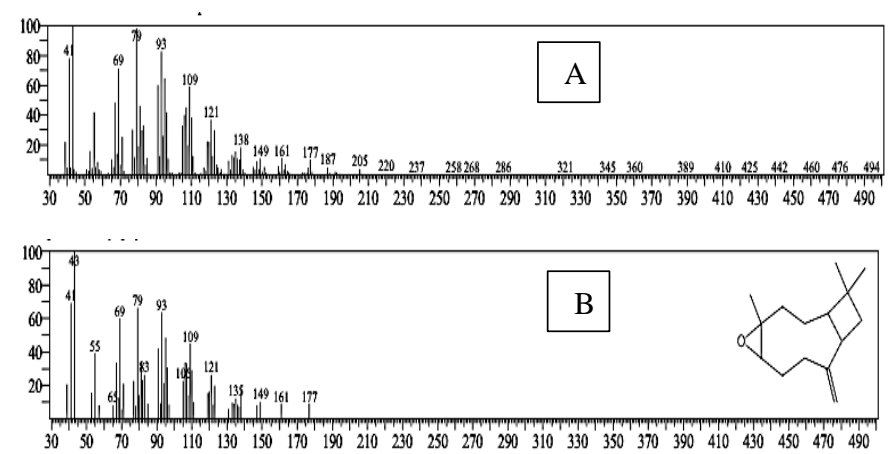

Figure 6. (A) Mass spectrum sample compared with (B) mass spectrum library of caryophyllene oxide with SI: 94 

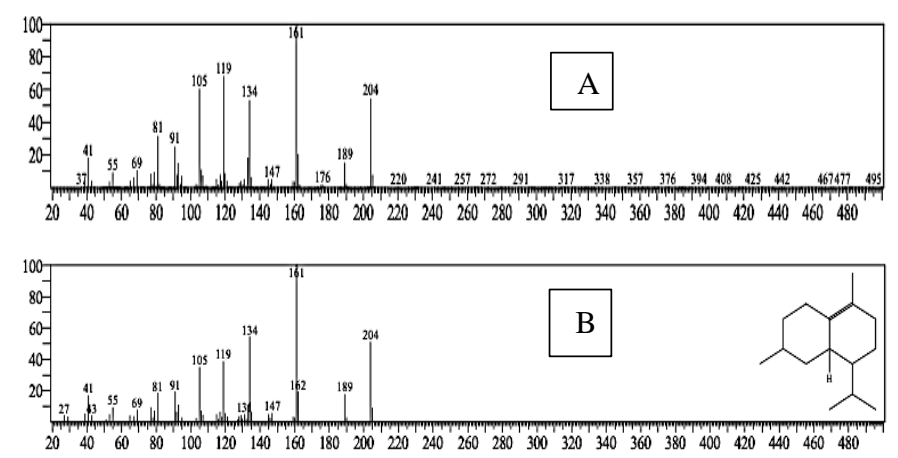

Figure 7. (A) Mass spectrum of sample compared with

(B) mass spectrum library of cadinene with SI: 94

Cadinene has a molecular weight of $204 \mathrm{~g} / \mathrm{mol}$, and in the mass spectrum (figure 7), the compound gives a molecular ion $(\mathrm{M}+)$ at an $\mathrm{m} / \mathrm{z}$ value of 204 . The parent molecular ion produces a mass spectrum fragment (m/z): 204, 189, 161, 134, $119,105,91,81$ with a base peak of $\mathrm{m} / \mathrm{z} 161$.

\section{B. Bioactive Compounds and their reported biological action}

Eugenol is an aromatic phenol compound that has a distinctive aroma. This compound has been used in the health sciences as an anti-inflammatory [14], anti-fungal [15], anti-cancer [16] and recent research have found eugenol which can be used as an inhibitor against Ebola virus [17]. Besides, eugenol compounds are also used in the food industry as scented substances [18] and antimicrobials in food [19].

$\beta$-caryophyllene, caryophyllene oxide, and cadinene is the bicyclic sesquiterpene group most contained in essential oils. Utilization in the field of pharmacology is so broad as anti-cancer, anti-oxidant, anti-microbial and analgesic [20].

\section{Conclusion}

From the above discussion, it can be drawn conclusion:

1. GC-MS analysis revealed that there were five most compounds contained in the clove oil of the leaves and stems, namely eugenol, $\beta$ caryophyllene, 1,4,7- cycloundecatriene-1,5,9,9 tetramethyl, caryophyllene oxide and cadinene.

2. The eugenol compound, which is contained in the stems is $55.83 \%$ bigger than the leaves, which is $45.3 \%$. But on the contrary, other compounds in the leaves are $\beta$-caryophyllene $(25.57 \%), \quad 1,4,7-\quad$ cycloundecatriene-1,5,9,9 tetramethyl $(8.65 \%)$, caryophyllene oxide
$(4.64 \%)$ and cadinene $(2,31 \%)$ greater than the other compounds in the stems, namely $\beta$ caryophyllene $\quad(19.72 \%), \quad 1,4,7-$ cycloundecatriene-1,5,9,9 tetramethyl (4.38\%), caryophyllene oxide $(3.48 \%)$ and cadinene $(0.5 \%)$.

3. Bioactive compounds obtained from this study indicate that the essential oil can be fully utilized for the manufacture of perfumery products, antivirus, antiseptic, and antimicrobial agent.

\section{Acknowledgement}

The authors are grateful to Politeknik Negeri Ujung Pandang for supporting the research through BOPTN funding by research scheme in 2021, and for permission to utilize the facilities of the chemistry laboratory for carrying out the research work effectively.

\section{References}

[1] D. Alighiri, W. T. Eden, K. I. Supardi, Masturi, and A. Purwinarko, "Potential development essential oil production of central java, indonesia," J. Phys., Vol. 1087, pp. 2-5, 2017.

[2] J. Towaha, "Manfaat eugenol cengkeh dalam berbagai industri di indonesia", (The benefits of clove eugenol in various industries in Indonesia), Perspektif, Vol. 11, No. 2, pp. 79-90, 2012.

[3] A. Budiawan, "Agroindustri Penyulingan minyak daun cengkeh (studi kasus di desa cangkring kecamatan ngadirojo kabupaten pacitan)", (Agroindustry Clove leaf oil refining (case study in Cangkring village, Ngadirojo sub-district, Pacitan district)), Berk. Ilm. Agridevina, Vol. 5, No. 2, pp. 41-53, 2016.

[4] T. D. Dhumal and J. S. Waghmare, "A pediculicidal activity of clove oil,” Int. J. Pharm. Sci. Res., Vol. 6, No. 2, pp. 857-865, 2015.

[5] W. Guan, S. Li, R. Yan, S. Tang, and C. Quan, "Comparison of essential oils of clove buds extracted with supercritical carbon dioxide and other three traditional extraction methods," Food Chem., Vol. 101, No. 4, pp. 1558-1564, 2007.

[6] Y. C. Yang, M. C. Wei, and S. J. Hong, "Ultrasound-assisted extraction and quantitation of oils from Syzygium aromaticum flower bud (clove) with supercritical carbon dioxide," $J$. Chromatogr. A, Vol. 1323, pp. 18-27, 2014.

[7] I. Gülçin, M. Elmastaş, and H. Y. Aboul-Enein, "Antioxidant activity of clove oil - A powerful antioxidant source," Arab. J. Chem., Vol. 5, No. 4, pp. 489-499, 2012.

[8] H. Cui, C. Zhao, and L. Lin, "The specific antibacterial activity of liposome-encapsulated Clove oil and its application in tofu," Food Control, Vol. 56, pp. 128-134, 2015.

[9] Y. F. Wang et al., "Antifungal effects of clove oil microcapsule on meat products," LWT - Food Sci. Technol., Vol. 89, No. August 2017, pp. 604-609, 2018.

[10] C. de Lima Boijink, C. A. Queiroz, E. C. Chagas, F. C. M. Chaves, and L. A. K. A. Inoue, "Anesthetic and anthelminthic effects of clove basil (Ocimum gratissimum) essential oil for 
tambaqui (Colossoma macropomum)," Aquaculture, vol. 457, pp. 24-28, 2016.

[11] M. Asl, A. Nazariborun, and M. Hosseini, "Analgesic effect of the aqueous and ethanolic extracts of clove.," Avicenna J. Phytomedicine, Vol. 3, No. 2, pp. 186-192, 2013.

[12] R. L. Putri, N. Hidayat, and N. L. Rahmah, "Eugenol purification from clove leaf oil with strong alkaline reactans of $\mathrm{KOH}$ and $\mathrm{Ba}(\mathrm{OH}) 2$ ( study on the concentration of the reactans )," J. Ind., Vol. 3, No. 1, pp. 1-12, 2014.

[13] Z. Xie et al., "The GC/MS analysis of volatile components extracted by different methods from exocarpium citri grandis," J. Anal. Methods Chem., Vol. 2013, 2013.

[14] X. Han and T. L. Parker, "Anti-inflammatory activity of clove (Eugenia caryophyllata) essential oil in human dermal fibroblasts," Pharm. Biol., Vol. 55, No. 1, pp. 1619-1622, 2017.

[15] A. F. Olea et al., "Antifungal activity of eugenol derivatives against Botrytis cinerea," Molecules, Vol. 24, No. 7, 2019.

[16] L. Yin, Z. Sun, Q. Ren, X. Su, and D. Zhang, "Methyl eugenol induces potent anticancer effects in RB355 human retinoblastoma cells by inducing autophagy, cell cycle arrest and inhibition of PI3K/mTOR/Akt signalling pathway," $J$. B.U.ON., Vol. 23, No. 4, pp. 1174-1178, 2018.
[17] T. Lane, M. Anantpadma, J. S. Freundlich, R. A. Davey, P. B. Madrid, and S. Ekins, "The natural product eugenol is an Inhibitor of the ebola virus In vitro," Pharm. Res., Vol. 36, No. 7, pp. 2-7, 2019.

[18] D. Chatterjee and P. Bhattacharjee, "Use of eugenol-lean clove extract as a flavoring agent and natural antioxidant in mayonnaise: product characterization and storage study," $J$. Food Sci. Technol., Vol. 52, No. 8, pp. 4945-4954, 2015.

[19] H. Shabaan, A. A. Ramadan, and E. A. Edris, "Ranking the antimicrobial activity of four principle essential oil components against some food pathogenic bacteria ranking the antimicrobial activity of four principle sssential," Vol. 11, January, pp. 1-4, 2020.

[20] S. S. Dahham et al., "The anticancer, antioxidant and antimicrobial properties of the sesquiterpene $\beta$-caryophyllene from the essential oil of Aquilaria crassna," Molecules, Vol. 20, No. 7, pp. 11808-11829, 2015. 